\title{
REVIEW
}

\section{Marine birds and plastic pollution}

\author{
Marie Y. Azzarello \& Edward S. Van Vleet \\ Department of Marine Science, University of South Florida, 140 Seventh Avenue South, St. Petersburg, Florida 33701, USA
}

\begin{abstract}
The intrinsic properties and widespread presence of plastic particles in the marine environment have profound effects on birds inhabiting the world's oceans. Industrial and user-plastics composed of polystyrene, polypropylene, polyethylene, styrofoam, and polyvinyl chloride are the most prevalent forms of plastic marine pollution. Their dispersal and accumulation, in average densities of 1000 to 4000 pieces $\mathrm{km}^{-2}$, are controlled by surface currents, wind patterns, and different geographic inputs. Seabirds in the order Procellariiformes are most vulnerable to the effects of plastic ingestion due to their smaller gizzard and their inability to regurgitate ingested plastics. Planktivores have a higher incidence of ingested plastics than do piscivores as the former are more likely to confuse plastic pellets with copepods, euphausids, and cephalopods. Hence, diet may be a major factor determining the quantity of plastic ingested. Physiological effects related to the ingestion of plastics include obstruction of the gastrointestines and of subsequent passage of food into the intestines, blockage of gastric enzyme secretion, diminished feeding stimulus, lowered steroid hormone levels, delayed ovulation and reproductive failure. As plastic manufacture and use increases and subsequent disposal at sea becomes more extensive, the impact of discarded plastic on birds inhabiting the marine environment may also be expected to increase.
\end{abstract}

The beauty and genius of a work of ant may be reconceived, though its first material expression be destroyed; a vanished harmony may yet again inspire the composer; but when the last individual of a race of living beings breathes no more, another heaven and another earth must pass before such a one can be again.

William Beebe $1877-1962$

\section{INTRODUCTION}

Although plastics have been produced in large quantities since the end of World War II, it was not until the 1970 's that the existence of widespread plastic pollution of oceanic waters was discerned. According to the National Academy of Sciences (1975) approximately $4.5 \times 10^{4}$ metric tons of plastic are discarded at sea annually. Since the production of nonbiodegradable plastics and subsequent waste disposal practices have been increasing worldwide, it is likely that levels of contamination will continue to increase and pose an escalating threat to the marine environ- ment, and specifically to marine birds. Distinct methods of foraging, breeding and molting as well as well-defined distribution patterns of seabirds result in varying degrees of vulnerability to plastic pollution. Some seabirds are more susceptible in their breeding quarters, others where they molt, and still others in places where they spend their term of immaturity. To evaluate the environmental threat posed by discarded plastics, it is crucial to understand their role in seabird ecology. A comprehensive review of plastic ingestion by marine birds has been provided by Day et al. (1985). Here we expand on several points made by Day et al., and include several species and aspects not discussed in detail in their review.

\section{NATURE AND SOURCES OF PLASTIC POLLUTION}

Much has been published in the last 10 yr on the prevalence of plastics as a pollutant in the marine environment. A large body of evidence has been gathered indicating widespread marine contamination by plastic jetsam discharged from ships (Wong et al. 
1974) and by polyethylene and polypropylene industrial pellets discharged in waste effluents (Carpenter \& Smith 1972, Carpenter et al. 1972, Colton et al. 1974, Gregory 1977, Morris 1980). Plastics present a problem in the environment because they float, are non-biodegradable, and only slowly degrade upon exposure to ultraviolet radiation. Extension of the service life of some plastics has been made possible recently by incorporation of ultraviolet light stabilizers and antioxidants. This has led to a corresponding increase in the persistence of plastics and their inherent problems in the environment (Dixon \& Dixon 1981).

Plastics found at sea may be classified into 2 major types based on their origin. 'User-plastics' are most conspicuous and consist of plastic materials directly used by man, such as plastic bags, cups, bottles, packaging materials, ropes and nets. These objects are routinely discarded from commercial and fishing vessels (Dixon \& Dixon 1981), although some originate from rivers and acean dumping of land-generated litter. Larger plastic items of ten break up to form smaller fragments that are more commonly observed in the oceans (van Franeker 1985).

The second, less conspicuous, type of plastic originates from industrial sources. These formulated and compounded plastics generally take the form of small cylindrical disks having a diameter of less than $4 \mathrm{~mm}$, although spherical and rectangular granules also occur. These small plastic particles are the industrial bulk material in which plastics are manufactured and transported prior to their transformation into userplastics by remelting and employing additives (van Franeker 1985). Colton et al. (1974) suggest that the widespread distribution of plastic debris in rivers, estuarine, and coastal waters of the United States is the result of improper wastewater disposal in the plastics industry. Polystyrene spherules from factory effluents may be carried down rivers, with some settling out at the mouths of the rivers and others being transported into coastal waters (Hays \& Cormons 1974). The most probable cause of compounded plastics in the open ocean is routine solid waste disposal at sea by individual vessels (Colton et al. 1974).

Beach observations show that the plastic composition of marine litter is more diversified nearshore and that it includes primary and secondary packaging, cargo-associated and engine-room wastes, and fishing gear (Dixon \& Dixon 1981). Presumably when fishing nets were made of plant fibers they disintegrated rapidly after being lost or discarded at sea. However, with widespread use of more durable nylon netting, the situation has deteriorated. Small and large fragments of monofilament net are now becoming an integral part of jetsam washed up on beaches (Bourne 1977). In 1975, approximately 13172 metric tons of fishing nets, lines, and buoys were discarded by fishing fleets into the world's oceans (National Academy of Sciences 1975). In the Bering Sea alone, about 145000 pieces of net fragments per year originate from the fishing industry (Merrell 1984). Since Japan has been the principal user of monofilament gill nets in the Bering Sea and North Pacific Ocean, Merrell (1984, 1985 ) suggests that the majority of nets and floats washed onto Alaskan beaches originate from Japanese fisheries. Gill net floats represented the greatest constituent of plastic litter on Alaskan beaches in Merrell's study.

\section{DISTRIBUTION OF PLASTICS IN THE OCEAN}

Plastic pellets have been reported in average densities of 1000 to $4000 \mathrm{~km}^{-2}$ on the surfaces of the North Atlantic, South Atlantic, and Pacific Oceans (Carpenter \& Smith 1972, Carpenter et al. 1972, Colton et al. 1974, Morris \& Hamilton 1974, Wong et al. 1974, Gregory 1977, Shiber 1979, Day 1980). Most oceanic areas investigated, however, have been in the vicinity of coastal industrial sources, near major shipping lanes, or influenced by wind and current conditions more likely to retain and accumulate floating material than to disperse it (Morris 1980). Hence these estimates are likely to be higher than the oceanic average.

Areas which have shown the highest concentration of plastics in coastal waters along the Atlantic seaboard of North America are those where most plastic manufacturing and processing companies are located in southern New England and the middle Atlantic states (Carpenter et al. 1972, Colton et al. 1974). Plastic sheets and pellets were the most abundant and most widely dispersed particles collected in continental shelf waters between Virginia and Rhode Island, with polystyrene spherules present in concentrations up to $14 \mathrm{~m}^{-3}$ (Carpenter et al. 1972). Sheets and pellets were also the only forms of plastics found in appreciable quantities in shelf waters south of Cape Hatteras, and in most stations in the Caribbean Sea and Antilles current area (Colton et al. 1974).

Carpenter \& Smith (1972) demonstrated the presence of small plastic particles in the surface of the Sargasso Sea with an average concentration of 3500 pieces $\mathrm{km}^{-2}$ occurring over a lateral distance of $1300 \mathrm{~km}$. Lower concentrations were detected in and directly east of the Gulf Stream, just south of Cape Hatteras and in the Yucatan Channel. No plastic debris was discovered at stations in the Straits of Florida, in the southeastern Gulf of Mexico, or in coastal and Gulf Stream waters south of Cape Lookout, North Carolina (Colton et al. 1974).

An early account of plastic spherules collected in 
British coastal waters by Morris \& Hamilton (1974) indicated that these particles were negatively buoyant (having a density of 1.08 ) and frequently contained occluded solid phases together with vacuoles. Infrared spectrophotometry confirmed that these plastics were composed of a modified polystyrene containing approximately $13 \%$ of a styrene-butadiene copolymer. In a later study of plastic on beaches of the United Kingdom, Dixon \& Dixon (1981) reported that fragmented plastic was found in $77.8 \%$ of the transects sampled (compared with frequencies of $34.2 \%$ for oil, $62.7 \%$ for wood). Plastic pieces were found in $94 \%$ of their transects taken on French and Danish beaches. Substantial plastic accumulation has also been noted along the beaches of Lebanon (Shiber 1979).

Polyethylene and polypropylene pellets were found to be principal contaminants of the sea surface in the Cape Basin area of the South Atlantic Ocean, an area quite remote from any obvious source of such debris (Morris 1980). Morris described these plastic particles as primarily hard white or colorless spherules or pellets having a diameter of 3 to $5 \mathrm{~mm}$. All had wellrounded ends suggesting extensive weathering.

In a survey of plastic particle pollution in the northern Pacific off central California, Baltz \& Morejohn (1976) found mostly small polyethylene cylinders, although styrofoam, synthetic sponges, and pieces of flexible food wrap and rigid plastic were collected as well. Most of the plastic cylinders had rounded rather than sharp edges, signifying substantial wear (Colton et al. 1974) which may have occurred either on the beach or in the stomachs of birds (Baltz \& Morejohn 1976).

Wong et al. (1974) sampled surface waters along latitude $35^{\circ} \mathrm{N}$ near the California coast, then north along $125^{\circ} \mathrm{W}$ to Victoria, British Columbia. Small 10.1 to $0.5 \mathrm{~cm}$ ) round colorless plastic pellets weighing 20 to $50 \mathrm{mg}$ each were found in 21 of 23 tows. The average concentration was $0.3 \mathrm{mg} \mathrm{\textrm {m } ^ { - 2 }}$ with a maximum concentration of $3.5 \mathrm{mg} \mathrm{m}^{-2}$, or 34000 pieces $\mathrm{km}^{-2}$.

As part of an environmental assessment program of the Alaskan continental shelf $\left(60^{\circ} 00^{\prime} \mathrm{N}, 147^{\circ} 30^{\prime} \mathrm{W}\right.$ to $59^{\circ} 38^{\prime} \mathrm{N}, 140^{\circ} 00^{\prime} \mathrm{W}$ ), Jewett (1976) reported pollutants recovered from several benthic trawls. Of the stations sampled, $57 \%$ were contaminated with refuse consisting primarily of plastic materials such as brown or green refuse bags, pieces of clear plastic (bait wrappers), and plastic straps used as cargo binding material. Much of this plastic debris was of Japanese and Korean origin.

A benthic trawl of the southeast Bering Sea during 1975-76 by Feder et al. (1978) brought up man-made debris consisting primarily of metal, rope (synthetic), plastic, and glass, with minor amounts of rubber, wood, cloth, and paper products. The various classes of debris collected during both years were similar except that plastic was much more prevalent in 1975. It is suspected that much of this debris was discarded from fishing vessels because debris-containing areas corresponded closely to southern Bering Sea fishing zones.

In the southern Pacific, plastic pellets collected on New Zealand beaches were primarily polyethylene and polypropylene (Gregory 1977). Pellet abundance, though highly variable, was greatest near important New Zealand industrial centers, exceeding 40000 pieces $\mathrm{m}^{-1}$. Even on beaches far-removed from potential industrial contaminants, significant quantities of pellets were detected.

Previous studies have demonstrated a high degree of patchiness in plastic distribution at sea. This patchiness is attributable to currents, winds, and different geographic inputs (Shaw \& Mapes 1979). Wong et al. (1974) observed that in the western Pacific, wind stress transports surface pollutants eastward to about $170^{\circ} \mathrm{W}$ where both a weakening in wind stress and a change in the prevailing winds to a southward direction occurs. At $143^{\circ} \mathrm{W}$, in a region of zero annual wind stress, an accumulation of plastic was observed (Wong et al. 1974). In other areas, such as the Gulf of Alaska, surface currents play a more dominant role in the dispersal of plastic particles (Day 1980). Morris (1980) has suggested that plastics are being transported globally by oceanic current systems, and as a result have now become as ubiquitous a contaminant of the world's oceans as tarballs.

In open ocean waters, denser plastic debris (e.g. polystyrene-styrene copolymers) gradually sinks to the denser, cold mid-water layers where it attains neutral buoyancy and remains suspended in the water column. This is likely to result in a substantial underestimate of the amount of plastic in the oceans since most studies report concentrations of plastic in surface waters only (Morris 1980).

\section{FATE OF PLASTICS}

Although plastic debris is generally quite resistant to microbial or chemical degradation, many plastics are transformed from their original nature in the marine environment. Based upon observations of plastic collected on west European beaches and in waters of western Europe, Dixon \& Dixon (1981) deduced the fate of plastic bottles in the marine environment. They suggest that bottles made from the major thermoplastics, especially high density polyethylene, are photodegradable at the air-sea interface. Photodegradation produces embrittlement in plastics and subsequent fragmentation, generally within 2 to 3 yr following their discard at sea (Dixon \& Dixon 1981). 
Major thermoplastic packaging materials have recently been developed with enhanced degradability upon exposure to ultraviolet light. By combining existing compounds with photosensitive additives or by incorporating minor amounts of co-monomers containing photosensitive groups, these treated plastics can be made to degrade faster in the environment. Reports confirm that a bottle subjected to this process will be reduced to fragmentable condition within 3 mo compared to 3 yr for its unmodified counterpart (Dixon \& Dixon 1981). Although plastics with enhanced degradability might well reduce the persistence of these materials in the marine environment, any such advantages could be offset by increases in the quantities used and therefore discarded at sea. In addition, extending the service life of some plastics has recently been made possible by incorporating ultraviolet light stabilizers and anti-oxidants during the manufacturing process (Dixon \& Dixon 1981). Hence the overall degradability of plastics currently being discharged to the ocean is still unclear. With regard to fishing nets, Wehle \& Coleman (1983) suggest that submerged nets may remain in the ocean for up to $50 \mathrm{yr}$. These nets are highly resistant to processes of degradation in the environment due to their minimum exposure to heat, light, and abrasion.

\section{CLASSIFICATION AND CHARACTERISTICS OF SEABIRDS}

The fact that seabirds are highly diverse in their behavior and adapt differently to the marine environment makes it somewhat difficult to characterize them as a group. Some sojourn to inland waters and open country for at least part of the year, and retreat to the sea only during inclement seasons, while others are year-round marine inhabitants. Many birds are typically marine and come ashore exclusively to roost and breed (Bourne 1976). Alexander's classic compendium, The Birds of the Ocean (1928) classifies penguins, albatrosses, 3 families of petrels, tropic birds, frigate birds, some pelicans, the gannets and boobies, some cormorants and shags, the phalaropes, skuas or jaegars, gulls, terns, skimmers and auks or alcids as seabirds. It is also possible to include the divers, grebes, and sea ducks all of which have a tendency to breed inland yet winter offshore (Bourne 1976).

Of particular interest to this paper are the 2 orders most extensively researched: Procellariiformes and Charadriformes (Table 1). The former includes the following: British storm-petrels, prions, Leach's stormpetrels, white-chinned petrels, greater shearwaters, sooty shearwaters, Manx shearwaters and fulmars. The latter group comprise the red phalaropes, skuas, gulls,
Table 1. Common and scientific names of marine birds referred to in text (after Harrison 1983)

\begin{tabular}{|ll|}
\hline Common name & Genus and species \\
\hline Order: Procellariiformes & \\
Black-footed albatross & Diomedea nigripes \\
Laysan albatross & Diomedea immutabilis \\
Kerguelan petrel & Pterodroma brevirostris \\
White-chinned petrel & Procellaria aequinoctialis \\
Soft-plumaged petrel & Pterodroma molis \\
Atlantic petrel & Pterodroma incerta \\
Wilson's petrel & Oceanites oceanicus \\
Common diving-petrel & Pelecanoides urinatrix \\
Broad-billed prion & Pachyptila vittata \\
Greater shearwater & Puffinis gravis \\
Sooty shearwater & Puffinis griseus \\
Manx shearwater & Puffinis puffinis \\
Litte shearwater & Puffinis assimilis \\
North Atlantic fulmar & Fulmarus glacialis \\
British storm-petrel & Hydrobates pelagicus \\
Leach's storm-petrel & Oceanodroma leucorhoa \\
Fork-tailed storm-petrel & Oceanodroma furcata \\
Grey-backed storm petrel & Garrodia nereis \\
White-bellied storm-petrel & Fregatta grallaria \\
White-faced storm-petrel & Pelagodroma marina \\
Order: Charadriiformes & \\
Red phalarope & Phalaropus fulicarius \\
Parakeet auklet & Cyclorrhynchus psittacula \\
Horned puffin & Fratercula corniculata \\
\hline
\end{tabular}

terns and waders. Birds of the order Procellariiformes tend to accumulate more plastic than do other species. However, quantities in the gizzard may vary greatly among species and individuals (Day 1980, Furness 1985a). Gulls, terns, skuas, and waders, as well as other Charadriiformes, habitually regurgitate indigestible parts of their food items, such as shell and fish bone (Hays \& Cormons 1974). Procellariiformes, however, have a constriction between the gizzard and proventriculus, which makes it more difficult for gizzard contents to be expelled (Furness 1985a). Although some Procellariiformes frequently regurgitate portions of their stomach contents, the regurgitation often consists only of stomach oil and there may be a tendency for these birds to retain hard indigestible objects such as plastics (Rothstein 1973). The low possibility of regurgitation of plastic particles, together with a smaller gizzard in which to accommodate them, causes Procellariiformes to be especially susceptible to the effects of plastic pellet ingestion (Furness 1985a).

\section{MODES OF INGESTION}

Ashmole (1971) classified seabirds on the basis of the method by which they ingest food. These methods include pursuit diving, surface-seizing, dipping, 
plunging and piracy. In what appears to be the mosı comprehensive work to date on plastic ingestion by marine birds, Day (1980) reported that 15 of 37 species of marine birds in Alaska contained plastic particles. The highest incidence of plastic was found in seabirds feeding by pursuit-diving $(26 \%)$ whereas $16 \%$ of Alaskan birds feeding by surface-seizing, $9 \%$ feeding by dipping, and none of those feeding by plunging or piracy contained plastic. The absence of plastic in birds feeding by plunging and piracy is reasonable, as plungers generally retrieve prey items beneath the water's surface, where less plastic is normally found. Birds feeding by piracy retrieve food dropped by other birds, food which is almost always fish (Ashmole 1971) and apparently contains little or no plastic (Day 1980).

Several known and potential prey items naturally inhabit the epipelagic zone, where plastics might be mistaken for prey or ingested along with them (Day 1980). Common white, light brown, and red plastic particles found at or near the water's surface often resemble the planktonic larvae of a number of crustaceans as well as the adults of other species (Mauchline 1980, Raymont 1983). Birds feeding predominantly on crustaceans or cephalopods generally have significantly higher frequencies of ingested plastic than do piscivores (Day 1980). Light brown plastic particles found in the surface layers of the ocean may also resemble eggs of many pelagic fishes and crustaceans. It is interesting to note that Colton et al. (1974) originally classified plastic particles caught in neuston tows as fish eggs. Thus, birds may also be 'mistaking' these particles for food (Day 1980). Plastics buried within egg masses have been recovered from regurgitations of Laysan albatross (Harrison \& Hida 1980). Based on these considerations, the relationship to prey type may actually be a better predictor of expected plastic ingestion than feeding method or foraging habitat, due to the resemblance of plastic particles to prey items (Day 1980).

The black-footed albatross Diomedea nigripes has been reported to scavenge trash thrown overboard while following ships for long distances (Fisher 1973). Plastics may be ingested by this method, but no specific reports have confirmed this mode of ingestion (Pettit et al. 1981). Similarly, this method of ingestion has been proposed by Furness (1983) for white-chinned petrels, greater shearwaters and sooty shearwaters, 3 species which feed primarily by surface-seizing and scavenging (Ashmole 1971).

Due to their inability to dive, Leach's storm-petrels consume indigestible objects floating within a few centimeters of the ocean's surface (Palmer 1962). It is likely that these particles were broadcast over the open ocean near ships or garbage dumps, since Leach's petrels infrequently feed in inland waters or follow ships in an effort to feed on dumped waste material, unlike Wilson's petrels Oceanites oceanicus, a related species (Petersen 1947). The absence of plastic in common diving petrels deserves mention as this species is strikingly disparate to other small Procellariiformes. Of the 19 diving petrels examined by Furness (1985a), 5 contained euphausiids with which brown plastic pellets could readily be confused. It is possible that because this species feeds by underwater pursuit-diving, it does not select plastics floating on the surface, as other petrel species do (Furness 1985a).

\section{OBSERVATIONS OF SEABIRDS IMPACTED BY PLASTICS}

The fact that marine birds swallow indigestible objects is well-documented. Kenyon \& Kridler (1969) examined the body contents of 100 Laysan albatross Diomedea immutabilis carcasses collected along the beaches and reefs of Hawaii. All foreign non-food items were collected and tabulated (Table 2). Only 9

Table 2. Indigestible material in 100 Laysan albatross carcasses collected along Hawaiian beaches and reefs from Kenyon \& Kridler 1969; reprinted with permission of the American Ornithologists Union Publishing Co.). F: frequency of occurence; G: greatest no. in one bird

\begin{tabular}{|lrccc|}
\hline Buoyant items & Number & Weight (g) & F & $G$ \\
\hline Pumice & 546 & 1063 & 85 & 93 \\
Plastic & & & & \\
$\quad$ Caps (bottle) & 83 & 69 & & \\
Misc. (toys) & 157 & 111 & & \\
Bag (polyethylene) & 1 & 3 & & \\
Total & 241 & 183 & 74 & 8 \\
Nuts & 12 & 63 & 12 & 1 \\
\hline
\end{tabular}

birds were void of objects. When placed in water, $99.4 \%$ of the items recovered from the dead birds were buoyant. Approximately $30 \%$ of these were plastic. Pieces of plastic scraps typifying those contained in the albatross carcasses were scattered about the beaches. Although at first it may seem that the beaches were the origin of indigestible items found in young albatross, this is unlikely since albatross rarely ingest food or other items from the shore. It is more probable that the plastic items were retrieved at sea by the parents and subsequently passed on with regurgitated food to their young (Kenyon \& Kridler 1969).

In a recent study of seabirds from Gough Island $\left(40^{\circ} 21^{\prime} \mathrm{S}, 9^{\circ} 53^{\prime} \mathrm{W}\right)$, South Atlantic Ocean, Furness (1985a) determined that the most highly contaminated 
species included greater shearwaters and white-faced storm-petrels (with up to 53 particles per bird). To a lesser degree broad-billed prions, white-bellied stormpetrels, gray-backed storm-petrels, a Tristan skua, little shearwater, Kerguelan petrel, Atlantic petrel, and soft-plumaged petrel were also found to be contaminated with plastic. The most contaminated birds contained plastic equal to $96 \%$ (white-faced storm-petrels) and $81 \%$ (greater shearwater) of their relaxed gizzard volume. Although smaller species tended to contain smaller particles, the smaller species appear to ingest more plastic than larger ones relative to body size. In a similar study, Furness (1985b) detected no particles in the intestines of any birds he examined. Though it is possible that plastic particles may be slowly worn down in the gizzard until small enough to pass through the intestines, there are no reports confirning that this actually takes place. Moreover, size frequency distribution implies that it probably does not occur since small particles were rarely found in the birds' gizzards (Furness 1985b).

Plastic particles and pellets have been reported in several other studies of surface waters and birds off southern Africa (Morris 1980, Ryan 1985) and in the South Atlantic (Bourne \& Imber 1982, Furness 1983). The fact that plastic particles were found in stomachs of Antarctic and sub-Antarctic species is of particular concern as it indicates that pollution is now commonly found in what has long been believed to be a relatively pristine environment.

Stomach contents of 22 fulmars collected in 1980 at Bear Island $\left(74^{\circ} 24^{\prime} \mathrm{N}, 19^{\circ} 00^{\prime} \mathrm{E}\right)$ and 29 fulmars collected in 1983 at $\mathrm{Jan}$ Mayen $\left(71^{\circ} 00^{\prime} \mathrm{N}, 09^{\circ} 00^{\prime} \mathrm{W}\right)$ were analyzed by van Franeker (1985). Although farremoved from industrial areas or major shipping routes, approximately $80 \%$ of the fulmars at both islands contained plastics. Plastic particles were also found in $39 \%$ of greater shearwater stomachs examined at Brier Island $\left(44^{\circ} 15^{\prime} \mathrm{N}, 66^{\circ} 22^{\prime} \mathrm{W}\right)$, and in $75 \%$ of those investigated from Placentia Bay (ca $47^{\circ} 00^{\prime} \mathrm{N}, 54^{\circ} 30^{\prime} \mathrm{W}$ ), eastern Canada (Brown et al. 1981). Similarly, $8 \%$ of sooty shearwater stomachs dissected at Brier Island and $5 \%$ at Placentia Bay contained plastic. Plastic ingestion by marine birds appears to be very widespread in the North Atlantic.

Ingestion of plastic by seabirds has been confirmed for a number of other species: fork-tailed storm-petrels Oceanodroma furcata, homed puffins Fratercula corniculata and parakeet auklet Cyclorrhynchus psittacula in the Aleutian Islands (Ohlendorf et al. 1978), adult and nestling Leach's storm-petrels Oceanodroma leucorhoa in Newfoundland and New Brunswick, Canada (Rothstein 1973) and in regurgitated gull and tern pellets from Long Island Sound, New York (Hays \& Cormons 1974).

\section{EFFECTS OF PLASTICS ON SEABIRDS}

Most investigators strongly caution that seabirds are likely to be injured by ingested plastic. Consumption of plastic particles could result in blockage or internal injury, although some seabirds may eventually regurgitate plastic pellets with other indigestible matter, thereby reducing harmful effects (Hays \& Cormons 1974, and many others).

Post-mortem examination of 4 young albatross confirmed that regurgitation of plastics from adult to chick occurs in this species (Pettit et al. 1981). Plastics were found in each chick. In one young bird, the large quantity of indigestible matter contributed to intestinal obstruction, while another bird with bulky plastics in the proventriculus had ulcerations in the mucosa. The retention of relatively small, smooth-surfaced plastics indicate that even small, hard objects do not ordinarily pass through the adult bird's proventriculus and gizzard to enter the lower digestive tract. Plastic particles were never observed in the excreta of this species (Pettit et al. 1981).

Birds that do not regurgitate solid matter can accumulate plastic which may interfere directly with their digestion. The presence of non-food items in birds' gizzards may not only cause gastrointestinal blockage (Day 1980), but may also be directly related to feeding stimulus and activity (Sturkie 1965). Hunger and satiety are controlled by receptors in the bird's hypothalamus where stimuli perceived by the central nervous system regulate food intake. Those factors stimulating appetite (hunger) include contraction of an empty stomach, low temperatures, and the sight of food; whereas those factors inhibiting appetite (satiety) include dehydration and distention of the stomach or intestines. Large quantities of plastic in a bird's stomach could therefore depress feeding activity by sustaining stomach distention or by preventing stomach contraction, signifying 'satiety' to the hypothalamus (Sturkie 1965). Birds collected from Gough Island in which plastic pellets were found in the gizzard invariably lacked fresh food in the proventriculus (Furness 1985a). Moreover, the presence of a large number of particles in the stomach may impede the secretion of gastric enzymes or the movement of food into the small intestine (Day 1980). Plastic ingestion may also be detrimental to reproduction, since DDT, DDE, PCB's and other chlorinated hydrocarbon pollutants associated with plastics may lower steroid hormone levels causing delayed ovulation (Peakall 1970).

Connors \& Smith (1982) report the incidence of plastic in a small but unique sample of migrating red phalaropes Phalaropus fulicarius, small sandpiper-like shorebirds adapted for swimming in surface layers and 
grazing upon zooplankton. These authors classified fat deposition in the phalaropes on a scale from 1 (no fat) to 5 (excessive fat) without knowledge of stomach contents. These values ranged from 1.5 to 3.5 (Table 3 ).

Table 3. Weight, fat condition and plastic particle occurrence in 7 red phalaropes, ordered by fat class (from Connors \& Smith 1982; reprinted with permission of Pergamon Press Ltd)

\begin{tabular}{|lccrrr|}
\hline Sex & Weight & $\begin{array}{c}\text { Fat } \\
\text { class }\end{array}$ & $\begin{array}{c}\text { No. } \\
\text { No. } \\
\text { of } \\
\text { pieces }\end{array}$ & $\begin{array}{c}\text { Total } \\
\text { weight } \\
\text { (g) }\end{array}$ & $\begin{array}{c}\% \text { of } \\
\text { stomach } \\
\text { volume }\end{array}$ \\
\hline M & 39.6 & 1.5 & 6 & 0.048 & 13.0 \\
M & 39.2 & 1.8 & 6 & 0.025 & 11.3 \\
F & 40.4 & 2.0 & 2 & 0.005 & 1.4 \\
F & 46.3 & 2.2 & 8 & 0.044 & 21.2 \\
M & 43.9 & 2.5 & 14 & 0.047 & 19.2 \\
F & 45.0 & 3.0 & 4 & 0.031 & 11.9 \\
& 50.1 & 3.5 & 0 & 0.000 & 0.0 \\
\hline
\end{tabular}

Although only one stomach contained recognizable food items (bamacle larvae and hyperiid amphipods), 6 of 7 stomachs were contaminated with plastic debris. Most of the recovered plastics were polyethylene 'nibs', an intermediate stage in the plastic manufacturing process (Colton et al. 1974); although a few particles were pieces of styrofoam. The results of Connors \& Smith (1982) indicated that fat class was negatively correlated with the number of pieces of plastic. Since fat condition plays a major role in determining flight range capabilities and possibly breeding success in this long-distance migrant, the potential effect carries considerable biological significance (Connors \& Smith 1982). Plastic contamination may produce physiological effects which threaten survival or reproductive success in regions far-removed from pollution sources (Holmes 1966, McLean 1969, McNeil \& Cadieux 1972, Ashkenazie \& Safriel 1979, Connors \& Smith 1982).

Wallace (1985) reports that seabirds encountering discarded nets face possible drowning. In their observations of net debris outside North Pacific fishing areas during 1978, Jones \& Ferrero (1985) reported that 99 seabirds were entangled in a $1500 \mathrm{~m}$ gill net. Similarly, Tull et al. (1972), Shaughnessy (1980), Fowler (1982), Piatt \& Reddin (1984) and Piatt et al. (1984) report seabird entrapment in abandoned fishing nets throughout the world's oceans.

Other adverse effects may also result from plastic ingestion. Although industrial plastic granules are normally considered to be composed of biologically stable plastic polymers, large amounts of additives including softeners, colorants, and anti-oxidants are often employed during the transformation from granules to user-plastics. These additives can be toxic in nature and may be readily assimilated from the ingested plastics (Aldershoff 1982). Carpenter et al. (1972) found that plastics recovered from marine surface waters contained polychlorinated biphenyls ( $\mathrm{PCB}$ 's) in a concentration of $5 \mathrm{ppm}$. Since PCB's are not added during the manufacture of polystyrenes, these authors suggested that the probable source was adsorption from ambient seawater. Based upon their similar physicochemical properties, other toxic organochlorines (such as DDT or DDE) may also be associated with oceanic plastic debris.

Studies concerning the effects of plastic pollution on marine birds are relatively new. Although few definitive studies have been reported, we have tried to elucidate several potential hazards associated with the ingestion of plastics. Although many of these potential hazards lie in the realm of conjecture, we believe that it is important to work toward prevention or prediction of these problems before the actual effects have been realized. Adverse biological consequences resulting from the present levels of plastic in the oceans appear to be insignificant for most marine organisms compared to the deleterious effects of other contaminants such as petroleum wastes, pesticides, or other chemical residues. Marine birds may be an exception to this rule. Escalating production of plastics, compounded by improper waste disposal practices, will predictably result in increases in the concentrations of these particles in rivers, estuaries and the open ocean. Birds inhabiting the marine environment might be expected to suffer the greatest consequences from this contamination.

\section{LITERATURE CITED}

Aldershoff, W. G. (1982). Gezondheidsaspecten van PVC voor levensmiddelen. Plastica 35: 58-60

Alexander, W. B. (1928). The birds of the ocean. Pitman, London

Ashkenazie, S., Safriel, U. N. (1979). Time-energy budgets of the semi-palmated sandpiper Calidris pusilla at Barrow, Alaska. Ecology 60: 783-799

Ashmole, N. P. (1971). Seabird ecology and the marine environment. In: Farner, D. S., Kind, J. R. (ed.) Avian biology, Vol. 1. Academic Press, New York, p. 223-286

Baltz, D. M., Morejohn, G. V. (1976). Evidence from seabirds of plastic particle pollution off central California. Western Birds 7: 111-112

Bourne, W. R. P. (1976). Seabirds and pollution. In: Johnston, R. (ed.) Marine pollution. Academic Press, London, p. 403-502

Bourne, W. R. P. (1977). Nylon netting as a hazard to birds. Mar. Pollut. Bull. 8: 75-76

Bourne, W. R. P., Imber, M. J. (1982). Plastic pellets collected by a prion on Gough Island, Central South America. Mar. Pollut. Bull. 13: 20-21

Brown, R. G. B., Barker, S. P., Gaskin, S. P., Sandeman, E. E. (1981). The foods of Great and Sooty Shearwaters, Puffinus 
gravis and $P$. griseus in eastern Canadian waters. Ibis 123 : 19-30

Carpenter, E. J., Anderson, S. J., Harvey, G. R., Miklas, H. P., Peck, B. B. (1972). Polystyrene spherules in coastal waters Science 178: 749-750

Carpenter, E. J., Smith, K. L. (1972). Plastics on the Sargasso Sea surface. Science 175: 1240-1241

Colton, J. B., Knapp, F. D., Burns, B. R. (1974). Plastic particles in surface waters of the northwestern Atlantic. Science 185: 491-497

Connors, P. G., Smith, K. G. (1982). Oceanic plastic particle pollution: suspected effect on fat deposition in Red Phalaropes. Mar. Pollut. Bull. 13: 18-20

Day, R. H. (1980). The occurrence and characteristics of plastic pollution in Alaska's marine birds. M.S. thesis, Univ. of Alaska

Day, R. H., Wehle, D. H. S., Coleman, F. C. (1985). Ingestion of plastic pollutants by marine birds. In: Shomura, R. S., Yoshida, H. O. (ed.) Proc. Workshop on the Fate and Impact of Marine Debris, 27-29 November 1984, Honolulu, Hawaii. U.S. Dept. Commerce, NOAA Techn. Memo. NMFS, NOAA-TM-NMFS-SWFC-54, p. 344-386

Dixon, T. R., Dixon, T. J. (1981). Marine litter survellance. Mar. Pollut. Bull. 12: 289-295

Feder, H. M., Jewett, S. C., Hilsinger, J. R. (1978). Man-made debris on the Bering Sea floor. Mar. Pollut. Bull. 9: 52-53

Fisher, H. I. (1973). Pollutants in the North Pacific Albatross. Pacif. Sci. 27: 220-225

Fowler, C. W. (1982). Interactions of northern fur seals and commercial fisheries. Trans. N. Am. Wildl. Nat. Resour. Conf. 47: 278-292

Furness, B. L. (1983). Plastic particles in three Procellaiiform seabirds from the Benguelan Current, S. Africa. Mar. Pollut. Bull. 14: 307-308

Furness, R. W. (1985a). Ingestion of plastic particles by seabirds at Gough Island, South Atlantic Ocean. Environ. Pollut. Series A 38: 261-272

Furness, R. W. (1985b). Plastic particle pollution: accumulation by Procellariiform seabirds at Scottish colonies. Mar. Pollut. Bull. 16: 103-106

Gregory, M. R. (1977). Plastic pellets on New Zealand beaches. Mar. Pollut. Bull. 8: 82-84

Harrison, C. S., Hida, T. S. (1980). The status of seabird research in the northwestern Hawaiian Islands. In: Grigg, R. W., Pfund, R. T. (ed.) Proc. Status Resource Investigations in the Northwest Hawaiian Islands. Sea Grant, Univ. of Hawaii, Hawaii

Harrison, P. (1983). Seabirds - an identification guide. Houghton Mifflin Company, Boston

Hays, H., Cormons, G. (1974). Plastic particles found in tern pellets on coastal beaches and at factory sites. Mar. Pollut. Bull. 5: 44-46

Holmes, R. T. (1966). Breeding ecology and annual cycle adaptations of the red-backed sandpiper (Calidris alpina) in northern Alaska. Condor 86: 3-46

Jewett, S. C. (1976). Pollutants in the northeast Gulf of Alaska. Mar. Pollut. Bull. 7; 169

Jones, L. L., Ferrero, R. C. (1985). Observations of net debris and associated entanglements in the North Pacific Ocean and Bering Sea, 1978-84. In: Shomura, R. S., Yoshida, H. O. (ed.) Proc. Workshop on the Fate and Impact of Marine Debris, 27-29 November 1984, Honolulu, Hawaii. U.S. Dept. Commerce, NOAA Tech. Memo. NMFS, NOAATM-NMFS-SWFC-54, p. 183-196

Kenyon, K. W., Kridler, E. (1969). Laysan Albatross swallow indigestible matter. Auk 86: 339-343

MacLean, S. F., Jr (1969). Ecological determinants of species diversity of Arctic sandpipers near Barrow, Alaska. Ph.D thesis, University of California, Berkeley

Mauchline, J. (1980). The biology of mysids and euphausiids. Adv. Mar. Biol. 18: 1-681

McNeil, R., Cadieux, F. (1972). Fat content and flight-range capabilities of some adult spring and fall migrant North American shorebirds in relation to migration routes on the Atlantic coast. Naturaliste can. 9: 589-606

Merrell, T R., Jr. (1984). A decade of change in nets and plastic litter from fisheries off Alaska. Mar. Pollut. Bull. 15: 378-384

Merrell, T. R., Jr. (1985). Fish nets and other plastic litter on Alaska beaches. In: Shomura, R. S., Yoshida, H. O. (ed.) Proc. Workshop on the Fate and Impact of Marine Debris 27-29 November 1984, Honolulu, Hawaii. U.S. Dept. Commerce, NOAA Tech. Memo. NMFS, NOAA-TMNMFS-SWFC-54, p. 160-182

Morris, A. W., Hamilton, E. S. (1974). Polystyrene spherules in the Bristol Channel. Mar. Pollut. Bull. 5: 26-27

Morris, R. J. (1980). Plastic debris in the surface waters of the South Atlantic. Mar. Pollut. Bull. 11: 164-166

National Academy of Sciences (1975). Marine litter. Assessing Potential Ocean Pollutants. A Report of the Ocean Affairs Board, Commission on Natural Resources. NASNRC, Washington, D.C.

Ohlendorf, H. M., Risebrough, R. W., Vermeer, K. (1978). Exposure of marine birds to environmental pollutants. U.S. Dept. Interior, Fish and Wildlife Service, Wildlife Research Report 9, Washington, D.C.

Palmer, R. S. (1962). Handbook of North American birds, Vol. 1. Yale Univ. Press, New Haven

Peakall, D. B. (1970). p,p'DDT: effect on Ca metabolism and concentration of estradiol in the blood. Science 168 592-594

Petersen, R. S. (1947). A field guide to the study of birds. Houghton Mifflin Co., Boston

Pettit, T. N., Grant, G., Whittow, G. C. (1981). Ingestion of plastic by Laysan Albatross. Auk 98: 839-841

Piatt, J. F., Nettleship, D. N., Threlfall, W. (1984). Net-mortality of common murres and Atlantic puffins in Newfoundland, 1951-81. In: Nettleship, D. N., Sanger, G. A., Springer, P. F. (ed.) Marine birds: their feeding ecology and commercial fisheries relationships. Can. Wildl. Serv. Spec. Publ., p. 196-207

Piatt, J. F., Reddin, D. G. (1984). Recent trends in the west Greenland salmon fishery, and implications for thickbilled murres. In: Nettleship, D. N., Sanger, G. A., Springer, P. F. (ed.) Marine birds: their feeding ecology and commercial fisheries relationships. Can. Wildl. Serv. Spec. Publ., p. 208-210

Raymont, J. E. G. (1983). Plankton and productivity in the oceans. Zooplankton, Vol. 2, 2nd edn. Pergamon Press, New York

Rothstein, S. I. (1973). Plastic particle pollution of the surface of the Atlantic Ocean: evidence from a seabird. Condor 75: $344-346$

Ryan, P. G. (1985). Plastic pollution at sea and in seabirds off Southern Africa. In: Shomura, R. S., Yoshida, H. O. (ed.) Proc. Workshop on the Fate and Impact of Marine Debris, 27-29 November, Honolulu, Hawaii. U.S. Dept. Commerce, NOAA Tech. Memo. NMFS, NOAA-TM-NMFSSWFC-54, p. 523

Shaughnessy, P. D. (1980). Entanglement of Cape Fur Seals with man-made objects. Mar Pollut. Bull. 11: 332-336

Shaw, D. G., Mapes, G. A. (1979). Surface circulation and the distribution of pelagic tar and plastic. Mar. Pollut. Bull. 10: $160-162$ 
Shiber, J. G. (1979). Pellets on the coast of Lebanon. Mar. Pollut. Bull. 10: 28-30

Sturkie, P. D. (1965). Avian physiology. Cornell Univ. Press, New York

Tull, C. E., Germain, P., May, A. W. (1972). Mortality of thickbilled murres in the west Greenland salmon fishery. Nature, Lond. 241: 271

van Franeker, J. A. (1985). Plastic ingestion in the North Atlantic Fulmar. Mar. Pollut. Bull. 16: 367-369

Wallace, N. (1985). Debris entanglement in the marine environment: a review. In: Shomura, R. S., Yoshida, H. O. (ed.) Proc. Workshop on the Fate and Impact of Marine Debris, 27-29 November, Honolulu, Hawaii. U.S. Dept. Commerce, NOAA Tech. Memo. NMFS, NOAA-TMNMFS-SWFC-54, p. 259-277

Wehle, H. S., Coleman, F. C. (1983). Plastics at sea. Natural Hist. 92: 20-26

Wong, C. S., Green, D. R., Cretney, W. J. (1974). Quantitative tar and plastic waste distributed in the Pacific Ocean. Nature, Lond. 247: 30-32

This review was submitted to the editor; it was accepted for printing on February 26, 1987 